\title{
Religión y reescalamiento: \\ ¿cómo santo Toribio colocó a Santa Ana en el mapa transnacional religioso?
}

\author{
RENÉE DE LA TORRE CASTELLANOS Y PEGGY LEVITT
}

En este artículo analizamos cómo la religión contribuyó al reposicionamiento binacional de Santa Ana de Guadalupe en los Altos de Jalisco, poblado en el que se ubica el santuario a Toribio Romo, santo patrón de la migración. Aunque los estudios sobre globalización centran su interés en el impacto de la economía en la formación de hot spots ciudades globales, con este estudio de caso queremos destacar el papel de la religión y la migración en el reescalamiento global de una localidad, aspectos que con frecuencia son ignorados por los estudiosos de las geografías globales. Argumentamos que esto fue posible debido a los cambios religiosos relacionados con otros cambios económicos y culturales.

PALABRAS CLAVE: reescalamiento global, santo Toribio, Altos de Jalisco, religión, migración

Religion and Rescaling: How Saint Toribio put Santa Ana on the Transnational Religious Map

RenÉE dE LA TORRE CAstellanos

Centro de Investigaciones y Estudios Superiores en Antropología Social-Occidente, Guadalajara, Jalisco, México reneedela@gmail.com

PEGGY LEVITT

Wellesley College, Boston, Estados Unidos plevitt@wellesley.edu

This article shows how religion contributed to the binational repositioning of Santa Ana de Guadalupe, in Los Altos, Jalisco, where there is a popular sanctuary to Saint Toribio Romo, the patron saint of migration. Although studies of globalization have been more interested recently in the impact of the economy on the formation of global city hot spots, in the case study presented here we highlight the role of religion and of migration in the rescaling of a place, factors which are often ignored by students of global geographies. We argue that the repositioning of this town on a world scale was possible thanks to religious changes that took place in combination with other economic and cultural changes.

KEYWORDS: global rescaling, Saint Toribio, Altos de Jalisco, religion, migration 


\section{Introducción}

asta mediados de la década de 1990, Santa Ana de Guadalupe, poblado ubicado en la región de los Altos de Jalisco, México, era un remanso rural aislado, apenas conectado con el mundo por un camino de terracería. ${ }^{1}$ El sacerdote que controlaba la ranchería, párroco de Santa Teresita en Guadalajara, ${ }^{2}$ tenía tanto poder local que hasta la década de 1970 prohibió la instalación de la escuela federal y la electricidad, porque con ella vendría la televisión y temía que estas innovaciones destruyeran el carácter moral del pueblo. ${ }^{3}$ Este cura era Román Romo, hermano de un joven sacerdote asesinado en una ranchería en Tequila, en 1928, durante la Guerra Cristera, llamado Toribio Romo. Román construyó una capilla en la que se exhibían los restos de su hermano y durante más de 40 años presidió el festejo de la Virgen de Guadalupe, el 12 de diciembre, al cual regresaban cada año los emigrantes de Santa Ana. "Nos reunimos porque queremos que nuestra sangre se siga reconociendo", explicaba en entrevista don Alfredo Jiménez en 1992. Sin embargo, esto cambió con la canonización de Toribio en el año 2000, cuando fue reconocido

1 El pueblo fue fundado en 1860 por cuatro familias: González, Jiménez, Martín del Campo y Romo.

Toribio Romo tenía lazos sanguíneos con estos últimos. Perteneciente al municipio de Jalostotitlán, se le denominó Santa Ana de Arriba, para diferenciarlo de Santa Ana de Abajo, en el municipio de San Juan de los Lagos. Cuentan que en sus orígenes la ranchería era muy productiva y a partir de la década de 1840 una sequía y los rezagos de la guerra hicieron que la mayoría de sus pobladores emigraran a Guadalajara y Jalostotitlán. A principios del siglo xx, después de la Cristiada, el cura Román Romo, hermano de Toribio, cambió el nombre del pueblo por Santa Ana de Guadalupe y construyó la capilla que hoy alberga los restos de santo Toribio para honrar el recuerdo del joven mártir (entrevista con Alfredo Jiménez, oriundo de Santa Ana de Guadalupe, Jalostotitlán, Jalisco, febrero de 1992).

2 Véase la historia del Barrio de Santa Teresita (De la Peña y De la Torre, 1990).

3 Entrevista con las señoritas Estefanita y Asunción Jiménez González, primas de Toribio Romo, quienes cuidaron el santuario y se encargaron del catecismo infantil (Santa Ana de Guadalupe, Jalisco, febrero de 1992). 
como uno de los 25 mártires cristeros, un grupo de sacerdotes asesinados durante la Guerra Cristera (1926-1929), que ofrendaron su vida en defensa del catolicismo. Al poco tiempo, la devoción regional en torno a Toribio cambió debido a que se esparció el mito de que el santo se aparecía a los migrantes para ayudarlos a cruzar la frontera de manera ilegal, obtener documentos migratorios o la green card, conseguir trabajo una vez que llegaban a Estados Unidos o protegerlos de la migra o de los abusos de los polleros. Este mito trajo consigo el progreso del poblado, que coincidió con la construcción de una carretera que hacía accesible la visita a la capilla, cuya fisonomía se transformó para convertirse en un santuario popular entre la comunidad transnacional.

En el presente, Santa Ana de Guadalupe recibe a miles de personas que llegan a rendir homenaje a santo Toribio en el lugar en el que se exponen sus ropas ensangrentadas y sus reliquias. ${ }^{4}$ Los fines de semana, alrededor de 10000 peregrinos locales e internacionales inundan el pueblo para externar su gratitud o hacer un pedimento. A su paso, depositan retablos en los que agradecen sus milagros. Al final de su visita compran mercancías religiosas con la imagen del santo, con las que propagan su culto en distintos lugares del país y Estados Unidos (De la Torre y Guzmán Mundo, 2010). En la actualidad, los peregrinos constituyen una derrama económica regional que ha contribuido a colocar este pequeño poblado en la geografía devocional religiosa, que si bien no abarca el mapa mundial, figura en el nacional, de México, y el binacional, de México-Estados Unidos.

La idea de que las ciudades globales han cobrado más importancia geopolítica que las mismas naciones en las que se encuentran debido a su función de centros nodales de la económica global es ampliamente aceptada. Pero hay un mapa religioso paralelo, con sus propios puntos de acceso y sus jerarquías de poder mundial que no ha recibido suficiente atención. Nos referimos a los santuarios como puntos nodales de comunidades o campos transnacionales. A diferencia de la expansión global de las grandes religiones impulsadas por los Estados-nación imperialistas - Roma-catolicismo, Inglaterra-protestantismo, Estados Unidos-congregaciones evangélicas, Arabia Saudita-Islam-, que han constituido ciudades globales, como La Meca o el Vaticano, y han colonizado grandes porciones del mundo, la transnacionalización desempeña tácticas de apropiación territorial que se implementan desde lugares periféricos y que ocurren en sentido contrario a los ejes de colonización (Argyriadis y De la Torre, 2012). En el presente, la religión, aunque ignorada con frecuencia, es una parte importante de los procesos de escalamiento o creación y reordenamiento de jerarquías espaciales.

En este artículo describiremos cómo la religión contribuyó al reescalamiento de Santa Ana de Guadalupe como lugar nodo o "punto caliente" — hot spot- de una geografía migratoria, y mostraremos que éste fue causado por su significado religioso. En su éxito también ha influido el hecho de que es un sitio estratégico en otros campos, como el económico y el cultural, lo cual es valorado por otros grupos de interés y agentes sociales para llevar a cabo proyectos que le imprimen otros significados, a veces complementarios, pero también contradictorios. Por un lado, se encuentra en una región que es el bastión emblemático de la cultura ranchera, central para la identidad mexicana tradicional, que muchos temen que está amenazada. A su vez, se encuentra

4

La intervención milagrosa de los santos tiene sus raíces en las prácticas de la religiosidad popular basadas en el culto a las reliquias, del cual se desprende el culto popular medieval de la peregrinación a los santuarios. Las reliquias "pueden ser trozos de tela u objetos que pertenecieron a los santos o sirvieron para su martirio, partículas de polvo o de otros materiales recolectados en el emplazamiento de sus tumbas, o incluso porciones de sus cuerpos; no tenían otro valor sino el basado en un conjunto muy específico de creencias compartidas" (Geary, 1991: 217). 


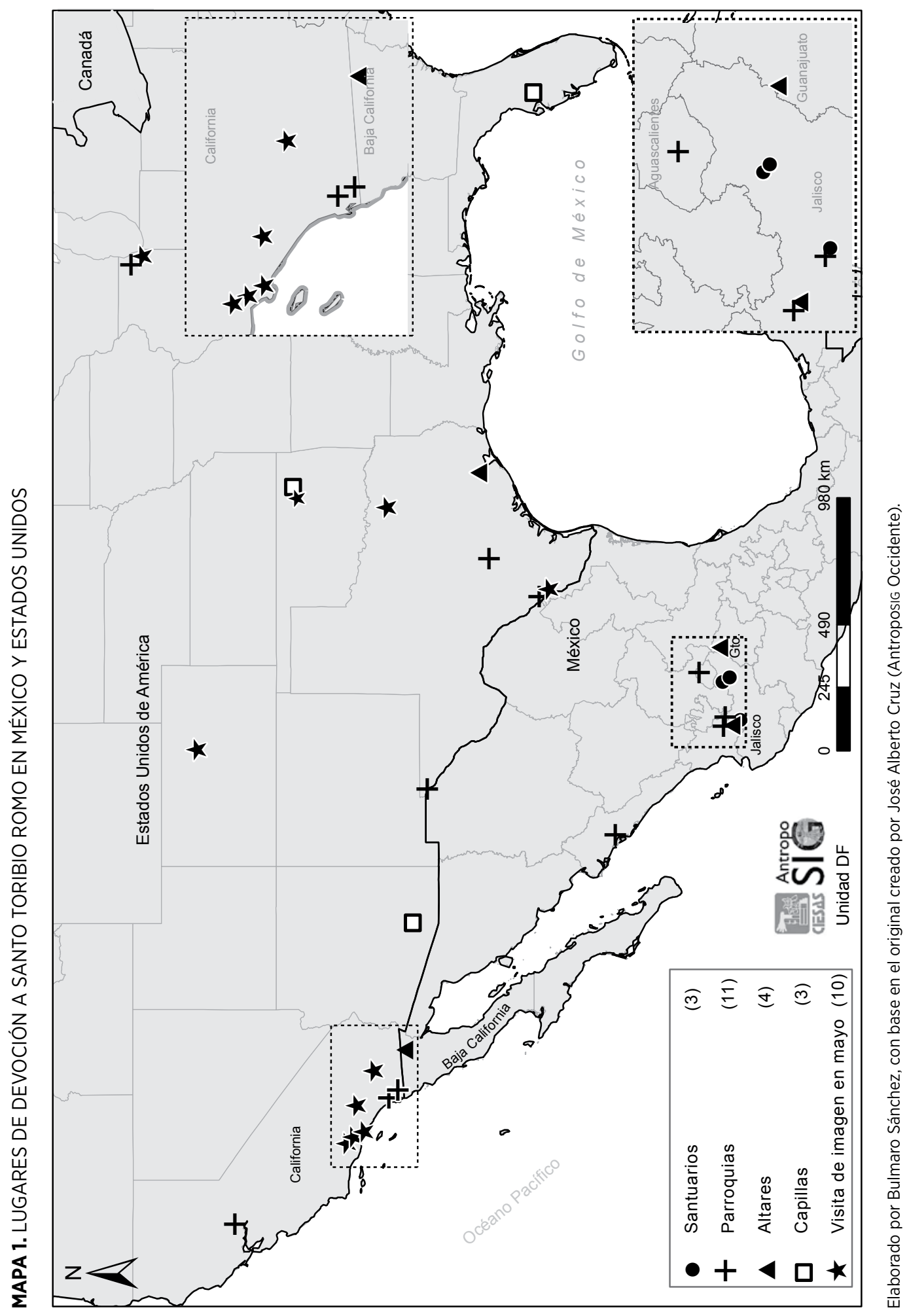


en la Ruta Cristera, a la que un segundo tipo de peregrino va a honrar la supervivencia del catolicismo y una forma específica de nacionalismo mexicano. Pero sobre todo, es una zona que ha experimentado una reconfiguración cultural profunda debido a la emigración hacia Estados Unidos. ${ }^{5}$ De acuerdo con Turner (1980), proponemos que se considere a santo Toribio como un símbolo dominante de la región, pues condensa los rasgos identitarios ${ }^{6}$ que han contribuido a mitificar a la región como cuna de la cultura ranchera y a los pobladores como practicantes de un catolicismo integral e intransigente, que dio lugar a la Guerra Cristera, y como portadores del fenotipo criollo o blanco. Es también un emblema multirreferencial que puede analizarse como un campo social de significados encontrados entre varios agentes y proyectos, que buscan instrumentar el símbolo para generar cambios sin rupturas con la tradición y reconocimiento de nuevos actores (Turner, 1980).

Santa Ana también tiene una variedad de significados para diferentes actores y representa una diversidad de intereses para conseguir metas distintas. En conjunto, estos usos y significados emocionales, históricos, comerciales y religiosos se han combinado para catapultar este antiguo remanso olvidado como un lugar destacado a distintas escalas, que van de lo regional a lo nacional y lo transnacional.

\section{Literatura comentada}

Nuestro proyecto reúne tres líneas de investigación que no se relacionan con frecuencia. La primera es la literatura sobre las economías urbanas y el papel de la cultura en su transformación. Los geógrafos llaman la atención sobre los impactos desiguales y heterogéneos de la globalización (Brenner, 2004). El neoliberalismo desafía las anidadas jerarquías tradicionales de lo local, regional y nacional mediante la distribución desigual de recursos y de poder hacia las regiones y ciudades en particular. Las ciudades, como argumenta Gillian Hart (2006), no se cierran como contenedores arraigados, más bien funcionan mediante procesos cargados de energía de constitución de conexión y desconexión en los que hay desviaciones, aberturas, contradicciones y posibilidades de alianzas. Las ciudades, y las localidades en general, se actualizan y son actualizadas por la intersección de sitios y planos de los campos sociales más amplios en los que se encuentran y por las estructuras culturales y los regímenes de gobernanza, que pueden ser tanto próximos como distantes en el globo.

No sólo tenemos que tomar en cuenta estas capas de poder múltiples, sino también los recursos y el establecimiento de la agenda. Tenemos que entender cómo y por qué las escalas se cruzan de manera diferente en cada lugar, cómo incorporan algunas localidades más céntricas y provechosas en circuitos de poder económico y político, y cómo marginan otras. Çaglar y Glick Schiller (2011) definen la escala como la clasificación y la reclasificación de las unidades socioespaciales en niveles de poder, influencia y relevancia diferentes e incluso interconectados. Ello "sirve como taquigrafía conceptual que nos permite hablar de la intersección entre dos procesos: la reestructuración, que incluye los movimientos de las diversas formas de capital y la reorganización de las relaciones de poder entre las unidades socioespaciales concretas de la

Retomamos el concepto de cultura como "la organización social de significados, interiorizados de modo relativamente estable por los sujetos en forma de esquemas de representaciones compartidas, y objetivados en formas simbólicas, todo ello en contextos históricamente específicos y socialmente objetivados" (Giménez, 2007: 49).

6 Con "rasgos identitarios" nos referimos al sistema de representaciones, valores y acciones compartidos por una colectividad, mediante los cuales se diferencian de los otros, se reconocen como parte de un grupo y son reconocidos por el resto. En el contexto contemporáneo de "modernidad tardía", las identidades no son fijas, se transforman y se negocian entre los actores de manera constante. 


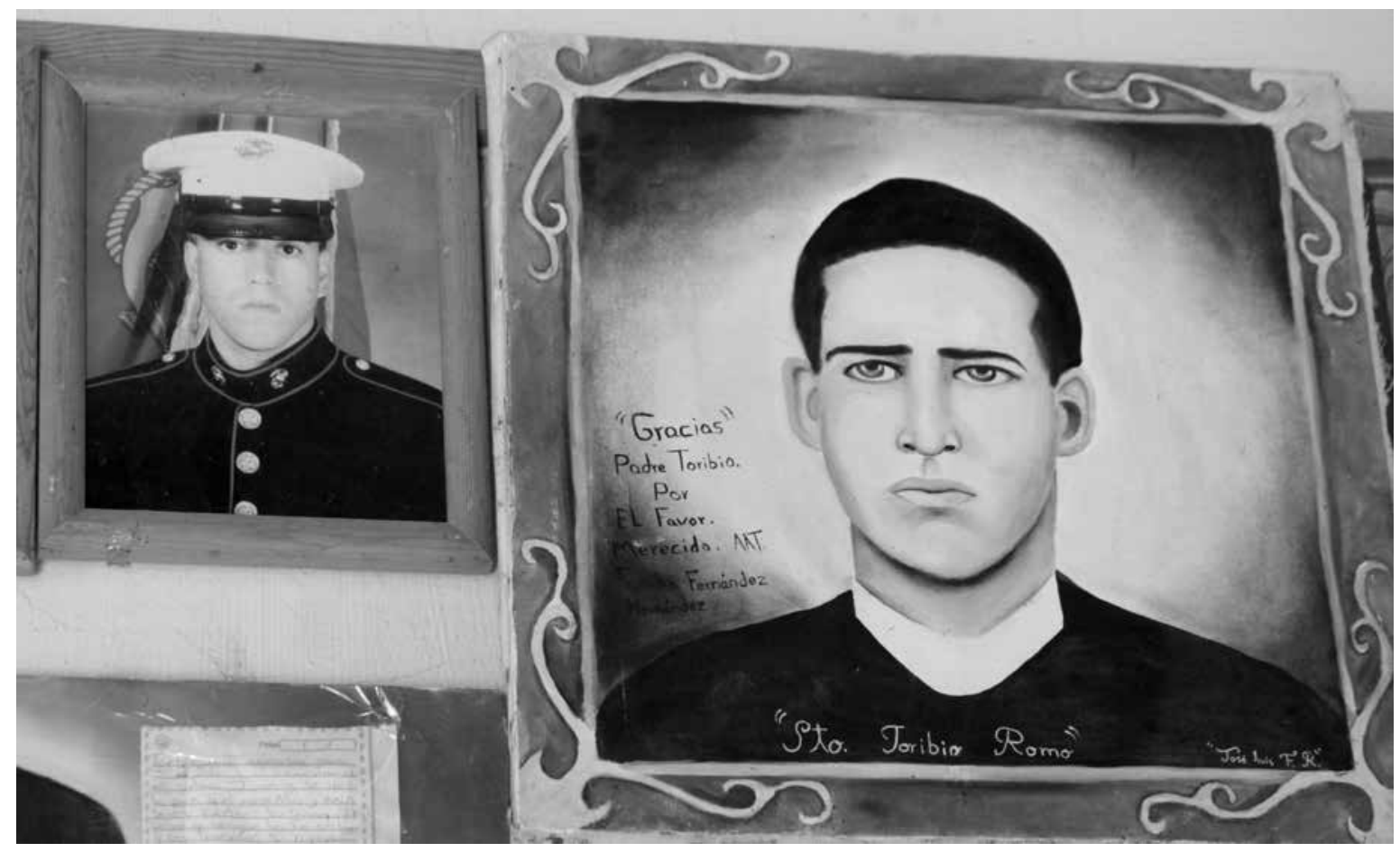

REnÉE DE LA TORRE • Santo protector de migrantes. Santa Ana de Guadalupe, Jalostotitlán, Jalisco, México, marzo de 2015.

gobernanza" (2011: 7). La escala de una localidad está determinada por su ubicación espacial frente a la intersección entre procesos de cambio de escala y de reestructuración económica.

La segunda línea estudia el papel de la migración en el cambio de escala de la influencia de las localidades. Gran parte de las investigaciones se centran en el papel de la cultura en la transformación de las economías urbanas (Florida, 2012; Kong, 2001). Kong, por ejemplo, escribe sobre tres fases de la política cultural en la historia de Singapur: la primera, para crear la nación fuerte de Singapur; la segunda, para crear un entorno de vida que atraiga la fuerza de trabajo transnacional necesaria para transformar Singapur en una ciudad global, y la tercera, para crear singapurenses globales que compitan en el escenario mundial. De hecho, las ciudades a menudo utilizan de manera favorable la inmigración y la diversidad para reinsertarse en el ámbito geopolítico gracias a la comercialización de su multiculturalismo (Çaglar y Glick Schiller, 2009; Çaglar, 2007; Bretell, 2006; Jaworsky et al., 2012). A pesar de ello, gran parte de este trabajo no presta suficiente atención a cómo los inmigrantes y los deportados acarrean este ordenamiento o reordenamiento de los centros urbanos y rurales.

En gran medida, ambos debates guardan silencio sobre la religión. Eluden la cuestión de lo que Van Dijk llama "una comprensión subjetiva de nociones geográficas de escala y de reposicionamiento escalar" (2011: 121). Shinji Hirai (2009) describe un proceso similar al tratar el cambio de escala imaginaria impulsado por los recuerdos y los sentimientos de nostalgia, la historia y el significado sagrado. Los lugares asumen mayor o menor protagonismo en función de sus posiciones cambiantes dentro de los imaginarios y recuerdos de estos paisajes religiosos mundiales. Por otra parte, las 
ciudades no siempre se reajustarán en su totalidad. Más bien, los puntos calientes particulares forman parte de determinados tipos de circuitos nacionales y mundiales de poder que, a su vez, se vinculan con determinadas localidades. Queremos recalcar que estos lugares no sólo se convierten en "calientes" por su importancia económica o política, sino también por su papel subjetivo-imaginario y su significado religioso.

¿Qué define, entonces, un punto caliente? En Ámsterdam y Róterdam, las relaciones entre los lugares específicos ocurren donde las asociaciones de inmigrantes, iglesias, sociedades funerarias y jefes tribales de la diáspora están creando, desde su localidad, un mundo ritual transnacional de interacción global. Estas instituciones vinculan los puntos calientes en varias ciudades, que a su vez reordenan las relaciones escalares de los espacios urbanos a los que están conectados. La Haya, según Van Dijk (2011), cobra más importancia que Ámsterdam como puerta de entrada mundial porque enlaza puntos calientes religiosos de escala y naturaleza diferentes. El reescalamiento transnacional del culto a santo Toribio se explica a partir del impacto regional que ha tenido la migración de los pobladores de los Altos de Jalisco a Estados Unidos. Por ello, Toribio Romo, aunque canonizado como mártir de la Guerra Cristera, hoy es considerado el santo patrón de los migrantes.

Una explicación es que muchos poblados en México practican el culto binacional a los santos. Esto genera un intercambio de remesas religiosas, ${ }^{7}$ tanto para el financiamiento de la fiesta, como para la circulación de bienes religiosos con los cuales los migrantes extienden su fe y la fiesta a los lugares de destino en Estados Unidos. Con su práctica, se establece un campo religioso transnacional que enlaza puntos calientes religiosos de escala y naturaleza diversas.

Por un lado, la fiesta religiosa se ha convertido en un evento clave para el regreso anual a los pueblos de origen, que favorece el mantenimiento de los lazos con la comunidad y genera una importante inversión, pues las divisas de los migrantes pagan la fiesta y financian obras de mejora del poblado (Arias y Durand, 2008). Por otro lado, las imágenes y la devoción a los santos "emigran” también a Estados Unidos, donde se les montan altares y se organizan festividades tradicionales en simultaneidad con sus fiestas en México (Levitt y Glick Schiller, 2004). Las imágenes católicas, al ser relocalizadas en otros contextos nacionales con regímenes de diferencia cultural (Segato, 2007), en los que los migrantes experimentan un contexto de diversidad étnica y nacional, se resimbolizan como emblemas de distinción étnica y nacional, para reconocerse entre sí y diferenciarse del resto (Odgers, 2008).

Las vírgenes migrantes y los santos viajeros representan también una estrategia de desplazamiento transnacional de referentes identitarios (Pratt, 2006: 29). Una explicación de su reescalamiento transnacional es que los migrantes mexicanos cargan sus imágenes y con ellas un pedazo de su tradición, tanto en su recorrido para cruzar la frontera como en el nuevo lugar de destino (Morán, 2000). Los santos, vírgenes y Cristos, si bien son emblemas identificadores de grupos particulares —en escala local y regional-, mediante su traslado y nueva localización son instrumentados como marcadores territoriales. Con ello, su devoción local se extiende y demarca nuevos territorios en los espacios adonde el viaje y la migración los lleva. De esta manera, los símbolos católicos, sacados de sus santuarios, se instrumentan para marcar el territorio en espacios extranjeros y anónimos, y tienen la capacidad de extender y refundar territorios locales en otros lugares (Segato, 2007).

7

Las remesas no sólo son monetarias. Con las remesas religiosas se ponen en circulación imágenes devocionales, objetos rituales y servicios religiosos, por medio de los cuales ocurre un intercambio (Rivera, 2011). 


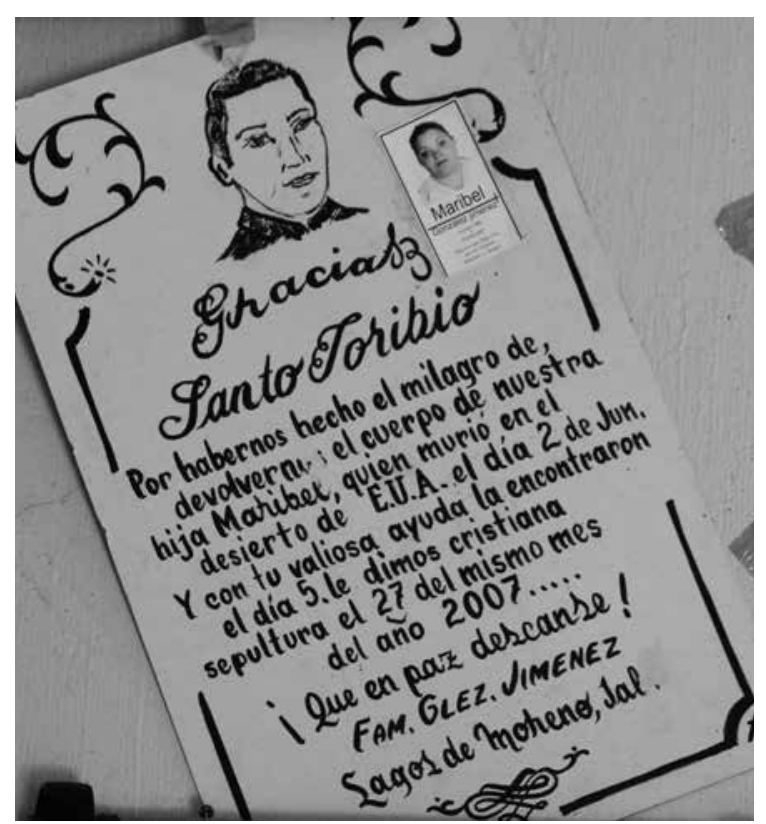

RENÉE DE LA TORRE • Retablo de agradecimiento a santo Toribio Romo. Santa Ana de Guadalupe, Jalostotitlán, Jalisco, México, marzo de 2015.

Ello también produce transformaciones en los sentidos practicados en las localidades, que atribuyen a los santos poderes protectores del nuevo problema migratorio. En muchos casos, la religiosidad popular ${ }^{8}$ se adecua al desplazamiento y replica imágenes que salen de sus santuarios y viajan adonde están los migrantes, como sucede con las vírgenes peregrinas y los Cristos migrantes ${ }^{9}$ que, como en este caso, transforman los santuarios de culto local o regional en lugares nodales de las redes de migración en un mapa binacional. Por ejemplo, en el Estado de México, esta acción ha permitido mantener los lazos y vínculos de una comunidad transnacional, entre los tlacotenquenses que se quedaron y los que residen en California, del otro lado de la frontera (Truax, 2011). Asimismo, se tiene noticia de réplicas de vírgenes conocidas de manera cariñosa como "vírgenes indocumentadas" porque cruzaron la frontera sin papeles (Hirai, 2009). De igual manera, el performance del vía crucis viviente ha sido retomado por la pastoral migratoria para dramatizar el paralelismo entre la pasión de Cristo — sufrimiento, dolor y muerte- y la de los migrantes (Iglesia en América 55, citado en Bobadilla, 2007). Otra estrategia en la que la religiosidad popular se implementa para rearticular la situación migratoria que divide comunidades es la peregrinación de santos y vírgenes a través de la frontera para demostrar que ni Dios ni la "madre de los mexicanos" — la Virgen de Guadalupe - necesitan documentos para acudir adonde están los suyos. Un ejemplo es el movimiento Antorcha Guadalupano, que cada año recorre 75 poblados de la ruta migratoria del este de México y Nueva York, divididos por la frontera pero unidos por una misma fe (Gálvez, 2009).

En suma, no podemos ignorar que la vida religiosa es un factor importante en el ordenamiento y reordenamiento de la clasificación de las jerarquías geopolíticas, tanto en sus aspectos subjetivos como en los poderosos intereses económicos y políticos que la rodean. Como mostraremos, las instituciones

Con "religiosidad popular " nos referimos, no a una religiosidad degradada o en oposición a la religión oficial, sino al sentido práctico de la religión en el que se negocia de manera permanente la continuidad de la tradición y la tradicionalización de lo nuevo. En la religiosidad popular, como resaltó Bonfil Batalla (1990), se renueva continuamente la identidad y la pertenencia a una tradición. "Los usuarios de religiones (populares) están poco preocupados por el origen de sus creencias y prácticas y sí en cambio, por la eficacia de su versión de la religión. Ellos se apropian de símbolos y los aplican o los reinterpretan en situaciones particulares con el fin de ayudarse a sí mismos (a resolver sus situaciones financieras o a curarse de alguna enfermedad). Los usuarios de la religión popular no tienen escrúpulos acerca de mezclar e incorporar elementos a fin de satisfacer sus necesidades, independientemente de que ellas sean espirituales o materiales" (Rostas y Droogers, 1995: 87).

$9 \quad$ Esta estrategia se describe en el estudio sobre la peregrinación de El Señor del Calvario, originario del poblado de Tlacotenco, Estado de México, hoy reconvertido en "Cristo de los migrantes" (Truax, 2011). 
y comunidades religiosas pueden modificar la escala de las localidades no sólo porque son parte de los paisajes imaginarios y físicos con los que sus seguidores se identifican, sino también porque son instituciones económica y políticamente poderosas. Además de la migración, habrá que considerar que las peregrinaciones crean paisajes religiosos mundiales, y dentro de ellos, dan forma a las jerarquías de poder. Las peregrinaciones se definen como los viajes realizados por personas en busca de una santidad, de la verdad, del milagro y de lo sagrado. Son a la vez institucionales y populares (Cohen, 1992). Los santuarios ofrecen puntos fijos y estables, ordenan el espacio y definen el territorio practicado en ciclos repetitivos. Los santuarios confieren centros y periferias. Demarcan la experiencia colectiva de dentro-fuera, cercano-lejano, privado-público, propio-anónimo. Representan paradas en las rutas y caminos, pero también imponen límites y fronteras (Barabas, 2004: 27). Como señala Aguilar, "las devociones alrededor de nuevas reliquias apuntan también a la difusión de estos centros en circuitos que se extienden allende las fronteras y se relocalizan en la construcción de comunidades imaginadas" (2012: 659).

Para entender esto, sólo hay que pensar en los intereses económicos y políticos masivos que cada año afectan el Hajj o el Camino de Santiago. Varios estudiosos describen las posiciones cambiantes y el estado de determinados lugares a medida que ascienden o retroceden en importancia como lugares de peregrinación. Eade y Garbin (2007), por ejemplo, describen la aparición de nuevos centros sagrados y periferias provocados por la migración congoleña y polaca a Londres. De la Torre (2008) argumenta que las peregrinaciones en México no sólo se procuran como prácticas devocionales tradicionales, sino que los santuarios, al ser espacios cargados de memoria y sentido de identidad, han sido revalorados en contextos de movilidad y transterritorialidad como anclajes de los sujetos transmigrantes, desplazados que por su condición liminal y en tránsito experimentan la falta de referentes de pertenencia territorial e identitaria. Las prácticas de peregrinación a los santuarios antiguos o recién fundados contribuyen a apropiarse de los territorios anónimos y a generar espacios de referencialidad comunitaria. La movilidad de la migración demanda una respuesta que combine tránsito y enraizamiento, ofrecida por la peregrinación y el santuario.

Con frecuencia, los lugares de peregrinación, como Santa Ana, se convierten en sitios de contención. Lugares históricos y culturales son recordados de forma diferente por los actores, que por lo general tienen intereses diferentes, incluso en conflicto, y deben desempeñar una variedad de funciones para los tipos de personas. Múltiples actores luchan por el replanteamiento y control del proceso de cambio de escala y las formas en que los recuerdos de los lugares específicos se narran y se despliegan (Legg, 2007; Macdonald, 2013; Daugbjerg, 2014) para recrear los sitios en la imaginación, rediseñar y reestetizar los paisajes. Lo que nos interesa es destacar "el reconocimiento que otorga la tradición [como] una forma parcial de identificación. Al re-escenificar el pasado introduce en la invención de la tradición otras temporalidades culturales inconmesurables" (Bhabha, 2002: 19). No es nuestro objetivo explicar la persistencia de la tradición, sino la manera en que nuevos actores con proyectos innovadores recurren al poder de la tradición y de los emblemas de identidad para reinscribirse en la sociedad. Si bien la versión oficial nacional o regional difiere de manera significativa de los modos mediante los cuales la gente normal reconoce el sentido y recuerda un lugar (Hoelscher y Alderman, 2004), a veces los recuerdos individuales y colectivos regionales están forjados en lo material y lo discursivo para "sustituir" o contradecir las memorias oficiales o para resistir la tendencia a olvidar (Azaryahu, 2003; Muzaini, 2013). 
De hecho, muchas personas y grupos han adoptado "políticas de escala" para apropiarse desde abajo, de manera simbólica y material, de los espacios.

En nuestro caso, la migración, el turismo, el folclorismo y la religión influyen en conjunto en el reposicionamiento de Santa Ana en un mapa binacional. Este poblado es atravesado por hilos de memoria histórica regionales que se entrelazan y crean una especie de palimpsesto compuesto por múltiples capas de memoria, por diferentes paisajes sobrepuestos que coexisten, se complementan entre sí e impulsan este proceso de cambio de escala. Nuestra historia, pues, no sólo se trata de cómo la religión reescala el lugar, sino también de cómo múltiples niveles de gobierno y actores con posiciones desniveladas compiten por contar la historia y resignificar sus símbolos dominantes de un modo determinado para legitimar sus proyectos. Por lo tanto, lo que explica la notable transformación de Santa Ana es su capacidad para ser utilizado por varios grupos para múltiples propósitos. Por ende, su capacidad de reescalamiento dependerá de su competencia para inspirar conexiones entre lugares y gente perteneciente a ellos (Alderman, 2003). Dicho de otra manera: "cuanto más resonancia entre la gente tenga un relato o una acción en términos de empatar sus significados, mayor será su impacto” (Muzaini, 2013: 393).

\section{Los múltiples hilos del reescalamiento de Santa Ana}

Describiremos al menos cuatro tramas interconectadas que se fomentarían la una a la otra y que han contribuido al cambio de escala de Santa Ana. En conjunto, forman una especie de caleidoscopio por medio del cual los residentes, turistas, emigrantes y peregrinos se apropian de este espacio que posee múltiples historias y significados, que se vuelven aún más significativos cuando funcionan/operan de manera simultánea.
Estas tramas establecen una negociación entre “actores-proyecto" diversos que actúan para definir la vocación del territorio mediante la constante intervención en la transformación del paisaje material de acuerdo con la concepción de paisajes culturales, es decir, imaginados y construidos socialmente. En esta dinámica entran en juego varias narrativas de identidad; muchas apelan a la memoria y otras velan por domesticar el progreso presente y futuro que les permite ingresar a la modernización. En el caso de Santa Ana, identificamos las siguientes tramas o proyectos que se entrecruzan: a) la reivindicación de los católicos como tierra santa; b) la memoria y la nostalgia de la cultura ranchera - catolicismo, mariachi, tequila y bellas mujeres-; c) la migración a Estados Unidos y la diáspora a los Altos, y d) el proyecto turístico para reconvertir la peregrinación en proyecto turístico. ${ }^{10}$

Una variedad de actores - Iglesia, gobiernos, pobladores, migrantes y empresas regionales - encabeza estos proyectos que representan sus lógicas e instrumentan recursos distintos. Su interacción amplía los marcos interpretativos, confiere reinterpretaciones y renueva la instrumentación funcional de los símbolos y las tradiciones. Veamos cada uno.

\section{LA TIERRA SANTA DE LAS RAÍCES CATÓLICAS Y EL MARTIRIO CRISTERO}

Santo Toribio simboliza la memoria de un pueblo que se reconoce por su fe en el catolicismo conservador. Más que en ninguna otra región de México,

10 Los datos se obtuvieron durante un trabajo etnográfico emprendido en 1990, que ha continuado de manera esporádica por décadas. La etnografía se basa en visitas al santuario —en 1990, 2001, 2008, 2014 y 2015—, donde se llevaron a cabo entrevistas con varios actores y se tomaron registros fotográficos de los exvotos, y notas en diarios de campo. 


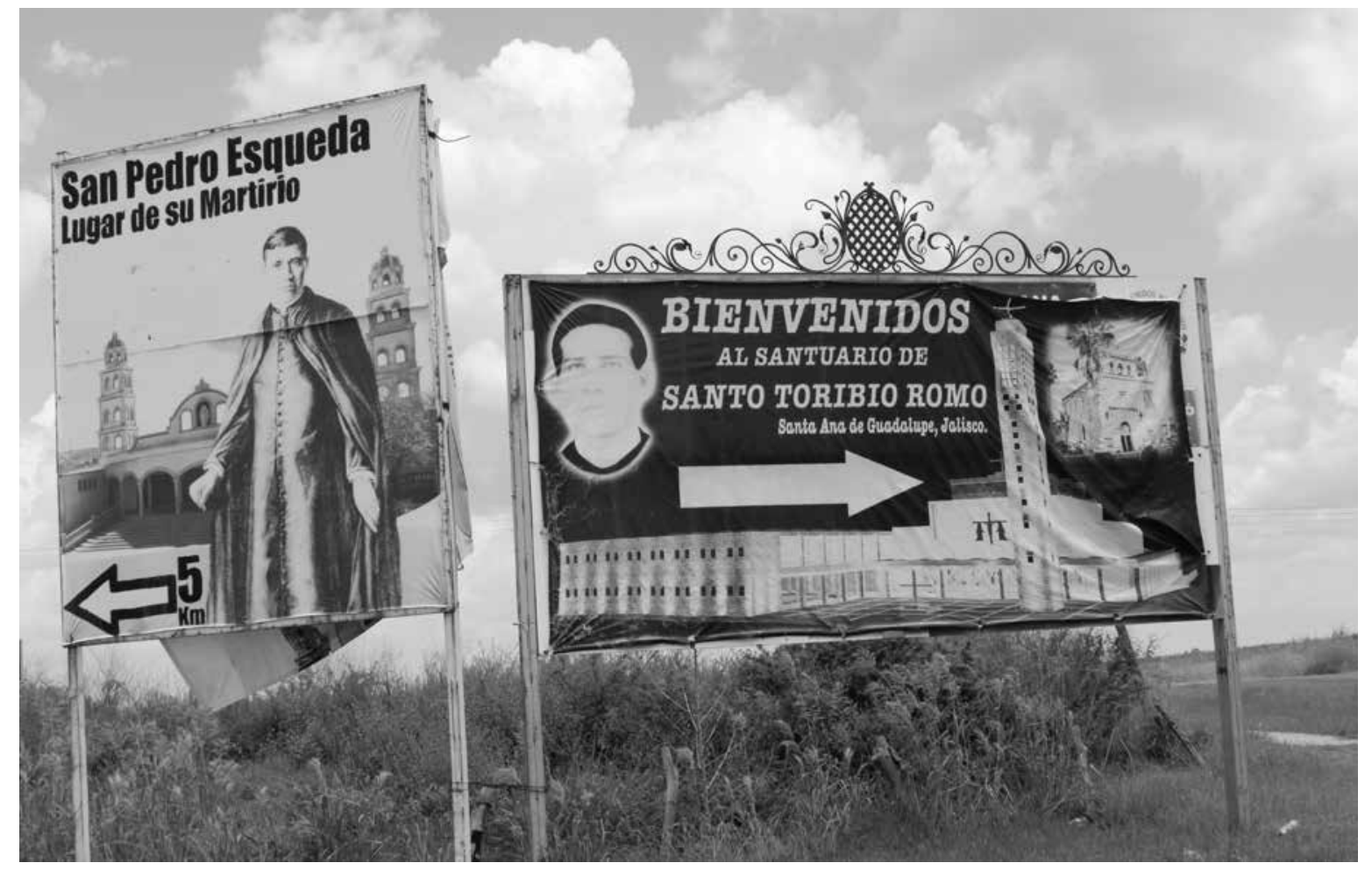

RenÉE de LA TORRE • Ruta Cristera. Santa Ana de Guadalupe, Jalostotitlán, Jalisco, México, marzo de 2015.

el catolicismo prevalece en el suelo, el espíritu y el entorno físico de los Altos de Jalisco. Los pueblos y ciudades de la región funcionan en torno a los sitios sagrados y los santuarios de peregrinación, que constituyen una geografía sagrada. La obra misionera traída por las órdenes religiosas durante la época colonial, en especial por los franciscanos, marcó la historia y la identidad de la región mediante el catecismo y la castellanización (González, 1983: 15). La religión católica logró unificar a los pobladores y vincular a los pueblos mediante las devociones a vírgenes, Cristos y santos traídos de España, los cuales se asociaron a milagros y apariciones. Con el tiempo, sus templos adquirieron fama de santuarios de peregrinación y se convirtieron en lugares de encuentro regional dentro de una geografía de intercambio comercial que coincidía con las fiestas religiosas. Éste es el caso de San Juan de los Lagos, región estratégica en el comercio porque es paso obligado para la explotación minera.

Los Altos es también tierra de rancheros, en su mayoría ganaderos que lograron articular la sociedad mediante las estrategias fincadas en las relaciones de parentesco, en la que el catolicismo jugó un papel decisivo para mantener un sistema oligárquico local (Fábregas, 1986; López, 1999). La región también fue tierra de vocaciones, en parte porque las familias acomodadas acostumbraban enviar a sus hijos varones a estudiar a los seminarios y algunos continuaban su carrera sacerdotal (Tapia, 1986), por lo que se construyeron múltiples seminarios que han sido semillero de sacerdotes y religiosos, hombres y mujeres, que han tenido un importante papel en la evangelización de todo el país. Aún en el presente representa una cuna de devociones sacerdotales, pero sobre todo sigue siendo "el núcleo duro del 
catolicismo conservador en México" (De la Torre y Gutiérrez, 2007). ${ }^{11}$

Destaca el hecho de que esta región fue un territorio que resistió los avances de la laicización y los embates anticlericales emprendidos en el siglo XIX por los liberales y los jacobinos, que lideraban un proyecto de nación establecido sobre la autonomía y supremacía del poder civil sobre el religioso (González, 2001: 10). Ante la aplicación de las leyes liberales, la Iglesia decidió cerrar los templos al culto público y el Estado emprendió una persecución religiosa. Los alteños tomaron las armas para defender su fe y salieron a combatir a los federales. Se identificaron como "cristeros" por su lucha en nombre de Cristo Rey. De 1926 a 1929, miles de habitantes de pueblos y rancherías de los Altos se sumaron a la Guerra Cristera, que dejó como saldo las muertes de combatientes y sacerdotes, venerados desde entonces como mártires cristianos. Algunos fueron santificados por el papa Juan Pablo II y se han convertido en emblema de una de las guerras más sangrientas que ha vivido el país, más importante para esta región que la Revolución agraria de 1910 (Meyer, 1973).

Aunque en la historia oficial del México priísta y en la misma institución católica se quiso silenciar este episodio, los católicos alteños se esforzaron por mantener vigente el recuerdo de los hechos; escribieron memorias y dejaron marcas en los lugares en los que murieron los mártires y combatientes. ${ }^{12}$ Una de las estrategias para mantener viva la memoria fue erigir ermitas y capillas, o poner cruces en los sitios en los que cada uno de los mártires derramó su sangre. Los familiares resguardaron los restos y las ropas ensangrentadas de las víctimas, incluso establecieron museos cristeros para preservar su historia. En el caso de santo Toribio, sus familiares construyeron las ermitas en Tequila, recogieron restos de su sangre, que hoy se exponen en algodones; guardaron las reliquias y la ropa ensangrentada, y en 1978 esto empezó a exhibirse en la capilla construida en su honor. Su hermano, el cura Román, se encargó de escribir su hagiografía, promover su beatificación y mantener su devoción entre la red de familias de Santa Ana. Sus primas se encargaron de registrar en un cuaderno los agradecimientos por favores y milagros recibidos, testimoniados por los devotos al mártir. En 1990, el cuaderno registraba 20 agradecimientos, la mayoría de pobladores de San Miguel el Alto, población vecina a Santa Ana, quienes agradecían milagros de curación de enfermedades terminales y secuelas de accidentes. Había uno especial, que narraba la aparición de un garrafón de agua en medio del desierto, el cual salvó la vida a dos hombres que se hallaban extraviados y que se habían encomendado a Toribio. Este profundo catolicismo, fundamental para la identidad del alteño, aseguró que la región se mantuviera como el último bastión de la movilización política cristiana, por medio del Partido Demócrata Mexicano (PDM).$^{13}$ Su historia y memoria religiosa, así como sus compromisos actuales con la fe, son los hilos que ubican a Santa Ana en un panorama sacro real e imaginario, que ha impulsado el aumento de su prominencia.

11 La cartografía de la diversidad religiosa en México, basada en los datos censales de población de 1950 a 2000 según su pertenencia a una religión, muestran que la región de los Altos de Jalisco mantiene porcentajes de población católica "extraordinariamente altos". El municipio de Jalostotitlán es uno de los 20 cuya población católica se encuentra por encima de 99.5\% (Gutiérrez, 2009). Hubo una ligera disminución en 2010, con 98.75\% de población que se declaró católica. Por ello se puede concluir que la región no ha experimentado las dinámicas de cambio religioso que se viven en otras zonas del país, sea por conversión a iglesias evangélicas o por abandono de la práctica.

12 Notas de trabajo de campo, enero de 1990.

13 Algunos de los últimos líderes del PDM, el cual representaba la ideología sinarquista, eran originarios de Santa Ana y familiares de Toribio Romo, como don Alfredo Jiménez. Notas de trabajo de campo, 22 de enero de 1990. 


\section{LA MEMORIA Y LA NOSTALGIA DE LA CULTURA RANCHERA}

Santo Toribio condensa también los rasgos de la cultura ranchera alteña que han contribuido a crear una especie de orgullo regional que enaltece sus costumbres y su fenotipo racial. Santa Ana de Guadalupe, lugar de nacimiento de Toribio y donde se localiza su santuario, es una ranchería del municipio de Jalostotitlán, en los Altos de Jalisco. La identidad alteña ha establecido una demarcación que le permite diferenciarse del resto del país, al mismo tiempo que reclama simbolizar la esencia de la nación. Algunos de estos rasgos son el paisaje natural semidesértico, la ganadería y el comercio como principales actividades productivas - que contrastan con la cultura agrícola de otras partes del país - y el orgullo por ser una población de gente blanca - como ellos dicen: "todos son güeros y de ojos claros"-, rasgos que los diferencian de los mestizos del centro del país y de los indígenas mexicanos. Este sentimiento le imprime a su identidad una especie de "superioridad racial", que ha influido en que se mantengan los altos niveles de endogamia que caracterizan el tejido social de la región (Fábregas, 1986).

De manera paradójica, los alteños demandan que ellos representan al México criollo. Argumentan que gran parte de los símbolos folclóricos mediante los cuales se identifica la mexicanidad provienen de Jalisco: los charros, la belleza criolla de sus mujeres, el tequila — bebida nacional-y los sones y las letras del mariachi. A partir de la segunda mitad del siglo xx, debido a la difusión del cine mexicano, la región de los Altos de Jalisco se convirtió en el referente emblemático del imaginario del México ranchero y criollo, convertido en un lugar común en la ideología de los medios masivos de comunicación, en especial del cine mexicano y la canción ranchera (Florescano, 2004). Estos elementos pueden considerarse estereotipos que constituyen una estampa alegórica —una postal— que reproduce "marcas" — como tequila, salsas, cervezas, restaurantes, dulces, etc.- para posicionar "lo alteño" en un mercado nacional y global. Incluso en el presente se usan para publicitar el atractivo turístico de la región en la página web de la Ruta Cristera en los Altos de Jalisco. ${ }^{14}$

De igual manera, la canción ranchera interpretada por mariachis ha inmortalizado el carácter macho y bravío del charro jalisciense. Estas canciones fueron propagadas con profusión por las disqueras y la radio - la XEW, La voz de la América Latina-y más tarde por los programas de televisión de variedades musicales. Así, la imagen del alteño se convirtió en una de las estampas preferidas del folclor nacional, coronado sobre todo en los ámbitos del nacionalismo cultural mediante la música, la canción y la danza, con el jarabe tapatío siempre presente en las coreografías regionales e incluido en los programas del Ballet Folklórico de México. Estas imágenes y sonidos continúan profundamente asociados con la región. Aunque ya no están presentes en la vida cotidiana, se reproducen como estereotipos que llaman a la nostalgia y al orgullo en los eventos festivos y se mantienen vigentes porque han estado abiertos a su mercantilización y modernización.

\section{LA MIGRACIÓN A ESTADOS UNIDOS Y LA DIÁSPORA A LOS ALTOS}

A lo largo de la historia y aún en la actualidad, los Altos de Jalisco son una de las principales regiones de expulsión de emigrantes a Estados Unidos. Los devastadores efectos de la Guerra Cristera hicieron que muchos hombres buscaran oportunidades en el Programa Bracero y encontraran empleo en la

14

Disponible en línea: <http://rutacristera.blogspot.mx/2010/ 03/la-elaboracion-de-esta-ruta-surge-ante.html>. Consultado el 1 septiembre de 2015 . 


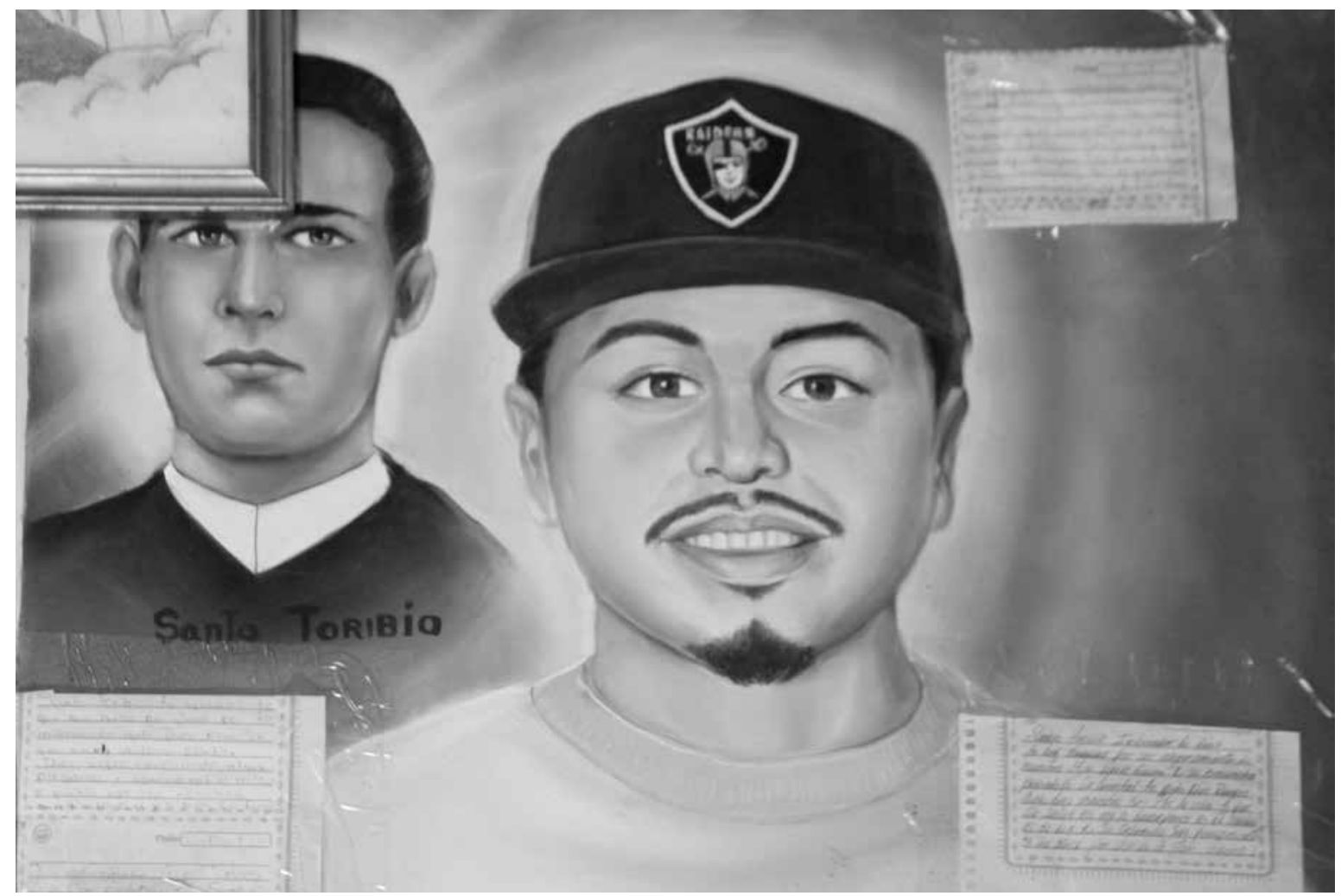

RenÉE de LA TORRE • Santo patrono de migrantes. Santa Ana de Guadalupe, Jalostotitlán, Jalisco, México, marzo de 2015.

agroindustria estadounidense. Estas raíces migratorias transformaron de manera sustancial la organización social de la región, su base económica y sus costumbres (Durand y Massey, 2003). En el municipio de Jalostotitlán, donde se ubica el santuario de santo Toribio, se estima que la mitad de la población en edad laboral vive "del otro lado". La región recibe beneficios económicos y depende en gran parte de las remesas que envían los migrantes. Cerca de 1.4 millones de jaliscienses vive en Estados Unidos y casi 2.6 millones de los nacidos allá son hijos de gente de la región. Numerosos habitantes de Jalisco tienen algún pariente que vive en "el Norte”. El estado ocupa el tercer lugar en la recepción de remesas de migrantes, después de Michoacán y Guanajuato. En 2010, 11.37\% de las familias de Jalostotitlán recibió remesas de Estados Unidos (Conapo, 2010).
Cuando Toribio Romo fue canonizado, la emigración a Estados Unidos todavía se consideraba algo temporal, una manera de ganar dinero suficiente para regresar a México y vivir mejor (Arias, 2016). Pero en realidad, ahora muchos migrantes han obtenido la ciudadanía estadounidense y no desean volver. Otros, sin documentos, no pueden obtenerla, y algunos más han regresado deportados a México en fechas recientes. A pesar de todo, cada año miles de migrantes regresan a sus comunidades de origen para asistir a los festejos del santo patrono. En muchos pueblos pequeños, en fechas cercanas, cada uno celebra su día del migrante (Durand, 1998; González de la Rocha y Escobar, 1990). Estos festejos constituyen importantes inversiones de dinero y suele ser cuando se hacen mejoras significativas al entorno físico y social. Además, son 
ocasiones de reencuentro entre los migrantes que regresan y sus familiares que se quedan en México, en las que se reactivan y fortalecen los lazos de continuidad y pertenencia. Los rituales y prácticas religiosas que los migrantes realizan con sus santos y comunidades de origen permiten que haya un sentido de continuidad sociocultural en el contexto de ruptura espacial. De hecho, el culto a los santos produce una economía política de la nostalgia que, en el caso de Santa Ana, contribuye también a la creciente prosperidad de la localidad (Hirai, 2009).

Esta dinámica ha transformado esta área rural de varias maneras, que a veces entran en conflicto. Algunas remesas se utilizan para remodelar el paisaje según las imágenes que motivan la nostalgia "ranchera" de los migrantes y los lugares se estilizan como un parque de atracciones o Disneylandia. Otros recursos se destinan a crear pueblos estilo hacienda y convertir campos antes usados para el cultivo del maíz en plantaciones de agave tequilero. Las instituciones y negocios que soportan esas vidas transnacionales también abundan en la región, como agencias de transferencias de dinero, como Western Union, y restaurantes que ofrecen comida californiana, china, tex-mex, pizza, hamburguesas y sushi, por ejemplo. De esta manera, los Altos se ha convertido en un símbolo icónico de un nostálgico pasado ranchero idealizado y codificado por industrias culturales y hecho posible gracias a las remesas. Al mismo tiempo, ha tenido grandes y significativas transformaciones al pasar de la granja familiar a la empresa agroindustrial, sobre todo de los ramos lechero y huevero, y al experimentar la gran fragmentación social que ha traído consigo la migración y la industrialización (López, 1999).

Instancias de gobierno y la Iglesia católica, por supuesto, tienen una participación en todo esto. El Gobierno del Estado de Jalisco, por medio de su Secretaría de Turismo, ha visto en las muestras masivas de fe y el regreso temporal de los migrantes una oportunidad para el desarrollo de la industria

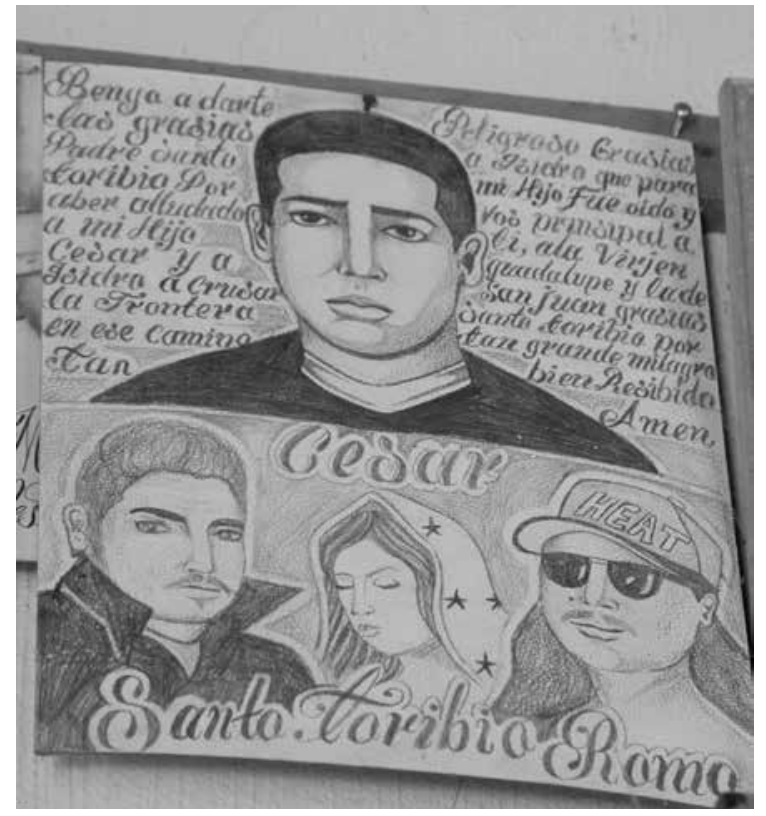

RENÉE DE LA TORRE • Agradecimiento a santo Toribio Romo por ayudar a cruzar la frontera. Santa Ana de Guadalupe, Jalostotitlán, Jalisco, México, marzo de 2015

turística. Desde el año 2000, con apoyo del nuevo gobierno del Partido Acción Nacional (PAN), de orientación católica y conservadora, se promovió la inversión en la Ruta Cristera para hacer caminos, remozar los pueblos y construir arcos de entrada. Por ejemplo, en la entrada de Jalostotitlán se construyó un arco que anuncia su identidad de pueblo diaspórico: "La tierra a la que todos quieren volver".

Tanto la migración como la religión han influido en el reescalamiento de Santa Ana y confluyen en la transformación del sentido del culto a santo Toribio. En el momento de su canonización, si bien era un mártir con devoción local, para la Iglesia católica nacional no era el más importante, sino uno más en la lista de 20 santos, encabezada por Cristóbal de Magallanes. Gracias al mito de su aparición como auxiliador de los migrantes fue reconocido como su santo patrón protector. Este hecho fue propiciatorio del reescalamiento y la prosperidad de Santa Ana. 
Los relatos acerca de esta transformación suelen contar que un hombre llamado José llegó al santuario buscando a alguien de nombre Toribio para pagar una deuda. José trató de cruzar la frontera tres veces, las mismas que lo regresaron, pero aunque se quedó sin dinero y sin esperanzas, Dios no lo abandonó. En su último intento, se encontró con un hombre llamado Toribio que le ofreció ayudarlo a llegar al "otro lado" y encontrar empleo. Así fue como José logró entrar a Estados Unidos. Una vez que alcanzó su sueño, le preguntó a su benefactor quién era y cómo se lo podía agradecer, y éste le respondió: "soy Toribio, si me buscas, cualquiera que viva en Santa Ana de Guadalupe me conoce". Dos años después, José fue a Santa Ana a darle las gracias a Toribio. Cuando preguntó por él, los habitantes del pueblo respondieron que ahí no había ningún Toribio excepto por "el padre Toribio, que descansa en la capilla". ${ }^{15} \mathrm{Al}$ entrar en la capilla, José vio la foto de Toribio, sus restos en el altar y algunas de sus ropas ensangrentadas en escaparates, y reconoció que era el mismo que le había ayudado (Guzmán, 2002).

Aunque nadie conoce con exactitud su origen, este relato milagroso se ha propagado como el fuego y ha convertido a un mártir cristiano en el santo patrón de los migrantes. Muchos otros relatos y testimoniales le atribuyen a santo Toribio apariciones como guía o protector de personas que cruzan la frontera hacia Estados Unidos. Sus seguidores dejan notas en su santuario que dicen cosas como "Gracias santo Toribio por ayudarme a cruzar el desierto", "Gracias por ayudarme a conseguir una visa" o "Gracias a ti conseguí un empleo". ${ }^{16}$ Los exvotos reproducen de manera continua el mito de su aparición en el trayecto fronterizo y de su intercesión milagrosa en los momentos de peligro y desamparo, pero también objetivan el compromiso de visitar Santa Ana para agradecerle a Toribio, "padre de todos los migrantes". En el siguiente testimonio impreso en un cartón, a manera de exvoto, se aprecia cómo se conjugan estos elementos:
Tecoman Colima Dagoberto Rodríguez Chávez sobrebibiente del trayle que abandonaron en Vitoria Texas el dia 10 de mallo del 2003 o glorioso y rey de los emigrantes Santo Toribio Romo. Te bengo a dar grasia por abernos sacado de ese treyle en que murieron 18 persona de los estados de Huajaca Colima y Puebla y de Honduras y de Estado de Mexico llo Dagoberto te bengo a dar grasias y a entregarte mi corazon porque aun no se me olbidan tus palabras cuando nos sacaste del trayle bestido de emigrasion aun recuerdo tus palabras ay de aquellos que sobrebiban iran a santa ana de Guadalupe Jalisco. Y preguntaran por Toribio Romo el fue el que me mando y luego dos dias antes de que tubieramos corte se nos presento un sacerdote disiendonos ban a salir pero ban a ir caminando a buscar a ese hombre que los ayudó y le daran las grasias es por eso hermanos que he venido desde de mi tierra caminando y pidiendo comida por el camino, él sabe que no traygo ni un sentavo ni para regresar a mi tierra. Pero bengo a darle grasias padre ten en tu seno y gloria al niño que tenia 6 años y a su padre que se murieron abrasados y a los hermanos de Juventino Rosas Gto. [...] Grasias Sto Toribio yo y mi familia te damos grasias [...] padre de todos los inmigrantes. Salida de Tecomán Colima. 29 de enero 2004 (transcripción textual del exvoto, santuario a santo Toribio, Jalostotitlán, marzo de 2015).

Aunque la Iglesia católica no reconoce estos milagros y prefiere fomentar el culto al santo como patrón de niños enfermos, ha explotado con habilidad la fama de patrón de migrantes y comercializa de manera activa parafernalia religiosa, y bendice

Extraído de la página de internet dedicada a las fiestas patronales de Lagos de Moreno, en octubre de 2001, en la sección dedicada a los "Visitantes migrantes", como una invitación para acercar a los paisanos a visitar el santuario. La página <www.lagosvirtual.com> ya no está disponible. 
estampas, novenarios, calcomanías y medallas que hacen alusión a la protección en el camino, la experiencia de la migración y el transporte y los caminos.

Otro aspecto clave para la popularización de santo Toribio es que es el único entre los santos mártires que cuenta con patrocinios. Además de ser el santo de los migrantes, es el santo del fútbol. El padre Gabriel González, párroco de Santa Ana, originario de San Miguel el Alto, donde se ubica la fábrica de camisetas de los equipos de la liga nacional de fútbol de la marca Atlética, promovió la visita de futbolistas y entrenadores de equipos populares - las Chivas de Guadalajara-. Estos eventos se publicitaron en medios de comunicación para que santo Toribio se reconociera como el patrón milagroso del fútbol. Este patrocinio fue alentado por la venta outlet ${ }^{17}$ de camisetas de fútbol en el Santuario de Santa Ana (entrevista con el padre Gabriel González, Santa Ana, 29 de diciembre de 2001).

Santo Toribio también es reconocido por ser un santo milagroso para sanar el cáncer. En el salón en el que los fieles ofrendan sus retablos, hay agradecimientos de milagros recibidos que incluyen los logros personales, como graduaciones o premios, trofeos de fútbol, nacimiento de bebés, sanación de secuelas de accidentes automovilísticos y protección contra secuestros y situaciones de inseguridad, muy frecuentes en la región.

Santo Toribio es un santo que protege la ilegalidad, pero dentro de los cauces católicos. La devoción hacia su figura se refuerza de manera constante con las imágenes canónicas centrales del catolicismo mexicano, en especial, por la fe que él dedicaba a la Virgen de Guadalupe. Por esa razón, Santa Ana cambió su nombre, originalmente de Arriba, por de Guadalupe. Esto se verifica en estampas y medallas del santo acompañado por la Virgen de Guadalupe, consecuente con la tradición mariana nacional. En fechas recientes también se le ha asociado con el nuevo santo Juan Pablo II, pues fue éste el papa que lo canonizó y es muy popular México. Además de comercializar la imagen de santo Toribio con san Juan Pablo II, en el mismo terreno del santuario se construyó un espacioso templo que lleva por nombre Juan Pablo II, al que llevaron algunas reliquias de Toribio Romo.

Por otro lado, la imagen de Toribio circula también en espacios de heterodoxia religiosa. Se vende en yerberías y botanicas de origen cubano, ${ }^{18}$ en las que se consiguen productos para los trabajos de magia y santería. Estos productos se han expandido en los mercados tradicionales y en los centros esotéricos de México y en las botanicas de Estados Unidos. Por ejemplo, en Los Ángeles hay una tienda que lleva su nombre, y en un comercio similar en el barrio de Queens, Nueva York, hay bustos de yeso de Toribio, entre orishas y santos populares de distintos países de Latinoamérica. ${ }^{19}$ Santo Toribio podría definirse como un santo "bisagra" (Bhabha, 2002), ya que es un santo católico que al brindar apoyo a una actividad que en Estados Unidos es tipificada y perseguida como ilegal - la inmigración indocumentada - compite con otros santos seculares. Compite, por ejemplo, con Juan Soldado, santo secular que brinda protección para evitar ser detenido por la Patrulla Fronteriza y para salvarse de los asaltos al cruzar la frontera. ${ }^{20}$

17 Venta de ropa de saldos o de segunda mano, cuyo costo está muy por debajo de su precio comercial.

18 Tiendas especializadas en artículos religiosos y para rituales de creencias de origen afrocaribeño. Ofrecen hierbas, velas, aceites, perfumes, lociones, jabones, libros, incienso, cráneos de animales, figuras y estampas de santos, y amuletos. Las primeras botanicas fueron fundadas por inmigrantes afrocaribeños y latinoamericanos en Estados Unidos a mediados del siglo xx.

19 Notas de trabajo de campo, barrio Jamaica, Queens, noviembre de 2015 .

20 La imagen se conoce como Juan Soldado. Su culto se realiza en la tumba de Juan Castillo, en Tijuana. La historia remite a un joven militar que en la década de 1930 fue condenado a fusilamiento por la violación y muerte de la niña Olga Camacho. Sin embargo, el juicio popular decidió años después exonerarlo y convertirlo en mártir, pues se dice que el delito fue cometido por un militar de alto rango (Valenzuela, 1992). 
El hecho de que ayuda a gente que emigra sin documentos, pues muchos mexicanos piensan que es justo aunque esté prohibido por la ley de Estados Unidos, hace a santo Toribio aún más popular entre sus seguidores. Al mismo tiempo, es legitimado por la jerarquía eclesiástica que, aunque argumenta que no fomenta el mito de su aparición en la frontera (entrevista con el padre Gabriel González, 29 de diciembre de 2001), alienta su reproducción y devoción mediante souvenirs que contienen oraciones para el migrante. Además, su culto es promovido por los párrocos a ambos lados de la frontera. Existen reportes de que santo Toribio se ha vuelto incluso más importante que Juan Soldado en Tijuana (Hernández, 2013).

Hoy existen templos dedicados a santo Toribio en distintos puntos de México: en Jalostotitlán y Guadalajara, Jalisco, y en Tijuana y Ciudad Juárez, Baja California, las principales ciudades fronterizas. Su primera presencia al otro lado de la frontera fue en el Children's Hospital de San Fernando, California, cuya devoción fue propiciada porque la abuela de una paciente, originaria de Jalostotitlán, llevó la imagen de santo Toribio y la dejó ahí, donde luego le hicieron una capilla (De la Torre y Guzmán, 2010). También se le han erigido altares en templos de los estados de California, Texas, Illinois y Nueva York. Ha sido retomado como símbolo de los derechos humanos de los inmigrantes por el movimiento pastoral de movilidad de Estados Unidos y entre la población hispana, que comprende población de Centroamérica y Sudamérica. Desde 2014, una imagen de santo Toribio en la que aparecen sus reliquias peregrina durante julio por varias parroquias del estado de California. Destaca una pequeña capilla en Tulsa, Oklahoma, erigida en 2008 —año en que Estados Unidos endureció las leyes migratorias-, en la que cada 21 de mayo se realiza una peregrinación de 4.2 millas en su honor. Participa la población latina con bandas típicas, danzas aztecas y charros que acuden a pedir por sus parientes que tienen que emigrar desde México (Fricker, 2014). Durante la procesión, conquistan el paisaje de Oklahoma en un etno-scape $e^{21}$ mexicano.

El desplazamiento del culto a Santo Toribio articula poblaciones de mexicanos en un mapa binacional, que conecta poblados del centro-occidente de México con California, Texas e Illinois, principalmente.

\section{EL PROYECTO TURÍSTICO PARA CONVERTIR EL PAISAJE EN INGRESOS}

La creación y promoción de la Ruta Cristera es otra maquinaria religiosa que impulsa el proceso de reescalamiento. La canonización de los 25 mártires cristeros representó una especie de revancha histórica que permitió a los habitantes de los Altos consagrar la región como un lugar de asediado pero intenso catolicismo y elevarla como una tierra santa purificada y sacralizada por los esfuerzos de los mártires. Una historia que había sido silenciada, o que había sido descrita sólo en términos de las "heroicas hazañas" de los liberales, podía ahora ser algo de lo que se hablara. Estos hechos contribuyeron también a un sentido de conexión y conmemoración de un pasado compartido con otras regiones de México fuertemente católicas, como Zacatecas, Aguascalientes, Guanajuato, Querétaro y Michoacán.

Después de la canonización de los mártires en 2000, el Gobierno del Estado de Jalisco implementó

21 O bien, etnopaisaje. Término propuesto por Appadurai (2001) para entender que a raíz del dislocamiento producido por las migraciones en la era global, con frecuencia se recrean paisajes étnicos distantes y dispersos de sus contextos históricos. En ellos se escenifica y practica la identidad étnico-nacional, en territorios de Estados-nación en los que son extranjeros. Los paisajes étnicos articulan territorios dispersos habitados y practicados por grupos étnicos transnacionales. 
un plan para reconvertir la fe, la peregrinación y el retorno migratorio en turismo. El estado podía abrir y expandir lo que ya era un destino popular - el santuario de la Virgen de San Juan de los Lagos- como un circuito más amplio que abarcase los templos dedicados a mártires cristeros, como santo Toribio. Por eso se construyó una autopista que brindó acceso a Santa Ana, con lo cual se habilitó la visita al santuario de santo Toribio. Pocos años después, la Secretaría de Turismo del Estado de Jalisco creó lo que se conoce ahora como la Ruta Cristera. Inspirados en la ruta de peregrinación del Camino de Santiago de Compostela, en España, buscaron inversión y promoción de la actividad turística. Implementaron un corredor y diseñaron el "pasaporte turístico", con la finalidad de ampliar las opciones de los peregrinos a la Basílica de San Juan de los Lagos y a Santa Ana de Guadalupe, para que conocieran otros nueve lugares con santuarios dedicados a los santos mártires cristeros. El proyecto turístico de la Ruta Cristera buscaba también ampliar su público hacia aquellos interesados en el folclor local, en adquirir artesanías o probar la gastronomía regional - por lo general, carnitas de puerco o dulces-, o bien, hacer un recorrido para degustar tequila en las fábricas en las que se produce. En esencia, la Ruta Cristera une todos los hilos inherentes a esta región. La religión se vuelve más atractiva porque se le coloca en relación con los otros significados de este espacio: sus funciones nostálgicas y económicas (Muzaini, 2013).

En la práctica, el proyecto no ha tenido el éxito esperado. En primer lugar, porque no ha sido apoyado por la Secretaría de Turismo federal, que ve con desconfianza su articulación con el fomento de la devoción católica. En cambio, los promotores estatales buscan posicionar la zona como una ruta histórica en la que se libró la Guerra Cristera (Martínez, 2011). Sumado a ello, la zona carece de infraestructura de servicios turísticos y la ruta no responde a un camino natural que permita establecer un circuito. Tampoco la Iglesia católica contempla un proyecto de promoción de pastoral turística pujante. ${ }^{22}$ Lo que sí ha funcionado es que cuatro millones de peregrinos visitan cada año el santuario de San Juan de los Lagos y más de 600000 acuden a Santa Ana, lo que fortalece la devoción regional y migrante a ambas imágenes (Martínez y Mínguez, 2014).

\section{Conclusiones}

En poco más de una década, santo Toribio pasó de ser un mártir poco conocido a un santo popular. Como resultado, Santa Ana se ha convertido también en un santuario importante para visitar. Los hilos económicos, religiosos y culturales se han combinado para transformarlo en destino popular para turistas, migrantes y peregrinos.

Al empezar el siglo Xx, Santa Ana de Guadalupe era un pequeño pueblo con una relevancia mínima en el mapa regional físico y simbólico de México, pero para la primera década del siglo XXI ya se había convertido en un sitio importante y reescalado en el campo social transnacional que conecta a México y los Estados Unidos. Su transformación demuestra el papel central que puede desempeñar la religión en los procesos de reescalamiento.

Pero la religión no actúa sola. Los lazos de la región con la cultura ranchera, una próspera industrialización e integración a los mercados domésticos e internacionales y un antiguo circuito de migración entre México y los Estados Unidos también echaron a andar el reescalamiento de Santa Ana. Aunque el poblado no es La Meca ni el Vaticano — ciudades

22 Comunicación personal con Rogelio Martínez, investigador del Centro Universitario de los Altos, de la Universidad de Guadalajara, especialista en el turismo religioso en los Altos de Jalisco, Tepatitlán, Jalisco, marzo de 2015. 


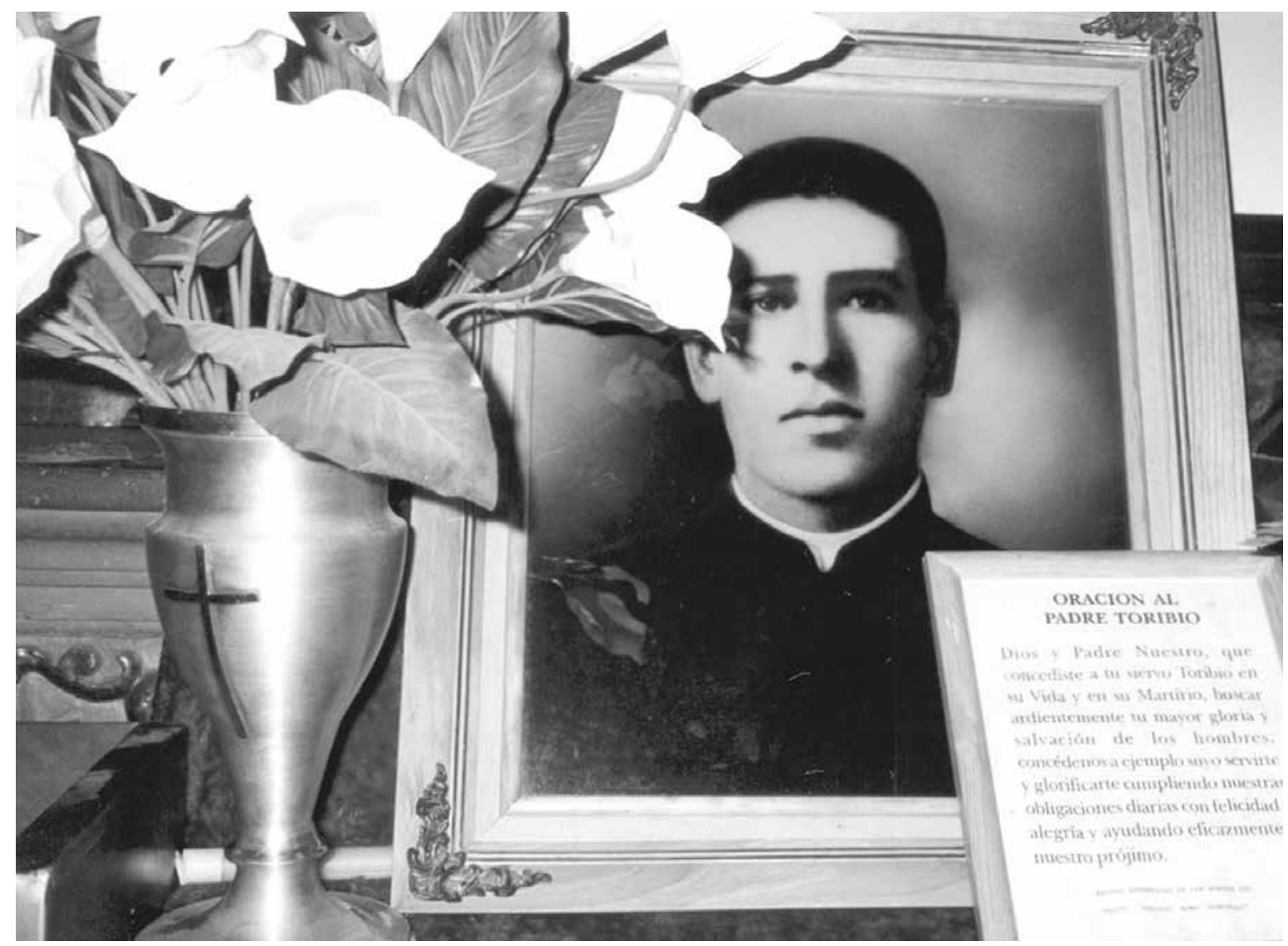

RenÉE DE LA ToRre • Altar con exvoto. Santa Ana de Guadalupe, Jalostotitlán, Jalisco, México, marzo de 2015.

religiosas de importancia global—, su significación espiritual y económica ha pasado de la marginalidad a una ubicación más central en los circuitos del campo binacional. Varios hilos históricos y económicos animaron su reescalamiento; al entrelazarse, crearon un amplio territorio imaginario, espiritual y emocional, al que muchos podían entrar.

Por "territorio emocional" nos referimos a que Santa Ana y sus alrededores están imbuidos de significado y se asocian a iconos espaciales y culturales con los que los migrantes y no migrantes se identifican con facilidad, y a que estas herramientas crean comunidades transnacionales no sólo imaginadas, sino simbolizadas y practicadas. Los recuerdos y símbolos relacionados con santo Toribio incluyen gran parte de lo que es querido para los alteños: las características físicas que los diferencian de los mexicanos mestizos e indígenas; el catolicismo popular y oficial, que celebra la lucha de los cristeros y transforma el área rural en la que ocurrió en una especie de tierra santa; los rasgos de la cultura ranchera, que son iconos de la identidad nacional mexicana criolla, y la identificación de los migrantes con su santo. Por ejemplo, para Luis Tarcisio González Ramírez, ex alcalde de Jalostotitlán, la canonización de Toribio representa un reconocimiento de su tradición: "un triunfo para nosotros, para nuestro modo de vida. Mucha gente de fuera llama a los alteños beatos, persignados, pero el tiempo da la razón" (De la Torre y Guzmán, 2010: 118). No obstante, 


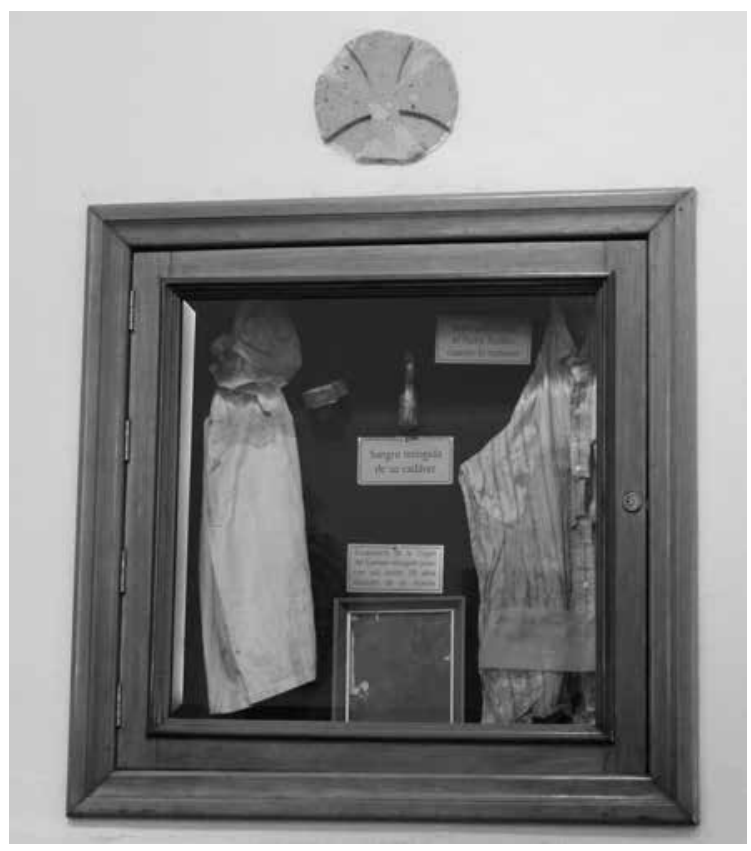

RENÉE DE LA TORRE • Reliquias: las ropas ensangrentadas de santo Toribio. Santa Ana de Guadalupe, Jalostotitlán, Jalisco, México, marzo de 2015.

para un migrante, santo Toribio significa un intercesor milagroso: "yo vine a Santa Ana a agradecerle a santo Toribio por su protección. Gracias a él pude cruzar con vida la frontera" (texto anónimo en un exvoto exhibido en el camarín del santuario de Santa Ana de Guadalupe). El santuario y santo Toribio son atractivos porque ofrecen a los visitantes un encuentro con la historia, con su tierra natal y con sus aspiraciones de regresar. Esta historia compartida, impulsada por la migración y la modernización, es accesible a todos, aunque los migrantes que dejan atrás el terruño, incluyendo aquellos que no pueden regresar cada año, la experimentan en distintos lugares y maneras.

El escalamiento y el reescalamiento de Santa Ana de Guadalupe son producidos por relaciones entre fuerzas históricas, económicas y religiosas, y entre la gente que las vive o las recuerda. Santo Toribio no sólo está presente en el paisaje religioso que imaginan sus seguidores y en su santuario, también se transporta con facilidad a altares caseros, espejos retrovisores de autobuses y autos, pequeñas capillas en hospitales y vecindarios, y en los negocios que llevan su nombre. En conjunto, todas las imágenes transportables marcan un territorio emocional con múltiples usos al que se ingresa por una variedad de puertas religiosas, históricas y económicas, que recibe con calidez a un gran número de personas y que puede abarcar muchas escalas y sitios. La importancia de Santa Ana estriba en que es un marcador fijo del retorno de los migrantes que lo visitan en su santuario, pero también su culto se desplaza y multiplica territorios - nuevos puntos calientes: parroquias, capillas o altares a santo Toribio-, gracias a la movilidad que logra mediante la propagación espacial de imágenes clonadas que viajan y establecen lugares de culto donde están los mexicanos.

Como resultado, el santuario de santo Toribio en Santa Ana es un lugar fijo y lleno de recuerdos, de esperanzas de regresar y nostalgia. Pero también es un lugar de progreso económico, movilidad y transnacionalismo. El símbolo de santo Toribio y su santuario es un hot spot que articula los niveles y fronteras de esta comunidad transnacional, al mismo tiempo que ayuda en las frecuentes negociaciones entre las aspiraciones locales, regionales, nacionales e internacionales de sus habitantes. Aunque parezca contradictorio, la nostalgia por la cultura ranchera que está siendo erosionada por el progreso y la modernización es contrarrestada por las peregrinaciones, la migración y el turismo que luchan por preservarla, y confluyen con eficacia en Santa Ana, lo que explica su notable transformación y su reescalamiento transnacional en el mapa religioso binacional. D 


\section{Bibliografía}

Aguilar Ros, Alejandra, 2012, "Los santuarios de Jalisco: hacia una tipología del centro sagrado", en Guillermo de la Peña y Jorge Aceves (comps.), Visiones múltiples. El occidente de México desde la antropología y la historia, t. 2, Centro de Investigaciones y Estudios Superiores en Antropología Social, Guadalajara, pp. 641-666.

Alderman, Derek, 2003, "Street Names and the Scalling of Memory: The Politics of Conmemorating Martin Luther King, Jr. within the African American Community”, en Area, vol. 35, núm. 2, pp. 163-173.

Appadurai, Arjun, 2001, La modernidad desbordada. Dimensiones culturales de la globalización, Fondo de Cultura Económica, Buenos Aires. Argyriadis, Kali y Renée de la Torre, 2012, "Introducción. Del objeto al método: los desafíos de la movilidad”, en Kali Argyriadis et al. (coords.), En sentido contrario. Transnacionalización de religiones africanas y latinoamericanas, Centro de Investigaciones y Estudios Superiores en Antropología Social, México, pp. 13-26.

Arias, Patricia, 2016, "La fiesta patronal en el mundo rural. Escenarios de ayer, dilemas de hoy", en Enrique Florescano y Bárbara Santana (coords.), La fiesta mexicana, Secretaría de Cultura/Fondo de Cultura Económica, México, pp. 276-318.

Arias, Patricia y Jorge Durand, 2008, Mexicanos en Chicago. Diario de campo de Robert Redfield 1924-1925, Universidad de Guadalajara/ Centro de Investigaciones y Estudios Superiores en Antropología Social/El Colegio de San Luis/Miguel Ángel Porrúa, México.

Azaryahu, Maoz, 2003, "RePlacing Memory: The Reorientation of Buchenwald”, en Cultural Geographies, vol. 10, núm. 1, pp. 1-20.

Barabas, Alicia, 2004, “Introducción: una mirada etnográfica sobre los territorios simbólicos indígenas”, en Alicia Barabas (coord.), Diálogos con el territorio, t. IV: Procesiones, santuarios y peregrinaciones, Consejo Nacional para la Cultura y las Artes/Instituto Nacional de Antropología e Historia, México, pp. 13-38.

Bhabha, Homi, 2002, El lugar de la cultura, Manantial, Buenos Aires.

Bobadilla Mata, Rodolfo, 2007, "Familias migrantes rotas por las deportaciones. Mensaje pastoral de monseñor Bobadilla con motivo del Día Nacional del Migrante", en Conferencia Episcopal de Guatemala. Disponible en línea: <http://www.iglesiacatolica.org.gt/20070831. pdf>. Consultado el 19 de junio de 2017.

Bonfil Batalla, Guillermo, 1990, México profundo. Una civilización negada, Centro de Investigación y Estudios Superiores en Antropología Social/Secretaría de Educación Pública, México.

Brenner, Neil, 2004, New State Spaces, Oxford University Press, Oxford.

Brettell, Caroline B., 2006, "Introduction. Global Spaces/Local Places: Transnationalism, Diaspora, and the Meaning of Home”, en /dentities: Global Studies in Culture and Power, vol. 13, núm. 3, pp. 327-334.

Çaglar, Ayșe, 2007, "Rescaling Cities, Cultural Diversity and Transnationalism: Migrants of Mardin and Essen”, en Ethnic and Racial Studies, vol. 30, núm. 6, pp. 1070-1095.

Caglar, Ayșe y Nina Glick Schiller, 2009, "Towards a Comparative Theory of Locality in Migration Studies: Migrant Incorporation and City Scale", en Journal of Ethnic and Migration Studies, vol. 35, núm. 2, pp. 177-202.

__ 2011, "Introduction: Migrants and Cities", en Nina Glick Schiller y Ayșe Çaglar (eds.), Locating Migration: Rescaling Cities and Migrants, Cornell University Press, Londres, pp. 1-22.

Cohen, Erik, 1992, "Pilgrimage Centres: Concentric and Excentric”, en Annals of Tourism Research, vol. 19, núm. 1, pp. 33-50.

Consejo Nacional de Población (Conapo), 2010, "Anexo B. Índices de intensidad migratoria México-Estados Unidos por entidad federativa y municipio", en Índices de intensidad migratoria México-Estados Unidos 2010. El estado de la migración, Consejo Nacional de Población, México. Disponible en línea: <http://www.conapo.gob.mx/work/models/CONAPO/intensidad_migratoria/anexos/Anexo_B1.pdf>. Consultado el 6 de febrero 2015.

Daugbjerg, Mads, 2014, Borders of Belonging: Experiencing History, War, and Nation at a Danish Heritage Site, Berghahn Books, Nueva York.

Dijk, Rijk van, 2011, "Cities and the Social Construction of Hot Spots: Rescaling, Ghanaian Migrants, and the Fragmentation of Urban Spaces”, en Nina Glick Schiller y Ayșe Çaglar (eds.), Locating Migration: Rescaling Cities and Migrants, Cornell University Press, Londres, pp. 104-122.

Dimensión Pastoral de la Movilidad Humana, 2012, "Informe de actividades de la Dimensión Pastoral de la Movilidad Humana, en el periodo 2006-2012”, Dimensión Pastoral de la Movilidad Humana-Conferencia del Episcopado Mexicano, México. Disponible en línea: <http:// www.sjmmexico.org/uploads/TBL_CDOCUMENTOS_70_2_56.pdf>.

Durand, Jorge, 1998, Política, modelo y patrón migratorios. El trabajo y los trabajadores mexicanos en Estados Unidos, El Colegio de San Luis, San Luis Potosí. 
Durand, Jorge y Douglas S. Massey, 2003, Clandestinos. Migración México-Estados Unidos en los albores del siglo xxı, Miguel Ángel Porrúa/ Universidad Autónoma de Zacatecas (colección América Latina y el Nuevo Orden Mundial), México.

Eade, John y David Garbin, 2007, "Reinterpreting the Relationship between Centre and Periphery: Pilgrimage and Sacred Spatialisation among Polish and Congolese Communities in Britain”, en Mobilities, vol. 2, núm. 3, pp. 413-424.

Fábregas, Andrés, 1986, La formación histórica de una región: los Altos de Jalisco, Centro de Investigaciones y Estudios Superiores en Antropología Social, México.

Fitzgerald, David, 2012, “A Comparativist Manifesto for International Migration Studies”, en Ethnic and Migration Studies, vol. 35, núm. 10, pp. $1725-1740$.

Florescano, Enrique, 2004, Imágenes de la patria, Taurus, México.

Florida, Richard, 2012, The Rise of the Creative Class. Revisited, Basic Books, Nueva York.

Fricker, Richard, 2014, "Patron Saint of the Border Crossers. How Santo Toribio Romo Came to Tulsa”, en The Tulsa Voice, agosto. Disponible en línea: <http://www.thetulsavoice.com/August-A-2014/Patron-saint-of-the-border-crossers/>.

Gálvez, Alyshia, 2009, Guadalupe in New York: Devotion and the Struggle for Citizenship Rights among Mexican Immigrants, New York University Press, Nueva York.

Geary, Patrick, 1991, "Mercancías sagradas: la circulación de las reliquias medievales”, en Arjun Appadurai (ed.), La vida social de las cosas, Consejo Nacional para la Cultura y las Artes/Grijalbo, México, pp. 211-242.

Giménez, Gilberto, 2007, Estudios sobre la cultura y las identidades sociales, Consejo Nacional para La Cultura y Las Artes/Instituto Tecnológico y de Estudios Superiores de Occidente, México.

González de la Rocha, Mercedes y Agustín Escobar Latapí, 1990, “La ley y la migración internacional: el impacto de la 'Simpson-Rodino' en una comunidad de los Altos de Jalisco", en Estudios Sociológicos, vol. 8, núm. 24, pp. 517-546.

González, Fernando, 2001, Matar y morir por Cristo rey. Aspectos de la Cristiada, Instituto de Investigaciones Sociales-Universidad Nacional Autónoma de México/Plaza y Valdés, México.

González, Luis, 1983, “Peculiaridades históricas del oeste mexicano”, en Encuentro, vol. 1, núm. 1, pp. 5-26.

Gutiérrez Zúñiga, Cristina, 2009, “La articulación de una región en torno al catolicismo. El centro-occidente de México”, en Alberto Hernández y Carolina Rivera (eds.), Regiones y religiones en México. Estudios de la transformación sociorreligiosa, Centro de Investigaciones y Estudios Superiores en Antropología Social/El Colegio de la Frontera Norte/El Colegio de Michoacán, México, pp. 199-220.

Guzmán Mundo, Fernando, 2002, Santo Toribio Romo: un símbolo regional polisémico, tesis de maestría en antropología social, Centro de Investigaciones y Estudios Superiores en Antropología Socia-Occidente, Guadalajara.

Hart, Gillian, 2006, “Denaturalizing Dispossession: Critical Ethnography in the Age of Resurgent Imperialism”, en Antipode, vol. 38, núm. 5, pp. 977-1004.

Hernández Hernández, Alberto, 2013, Frontera norte de México. Escenarios de diversidad religiosa, El Colegio de la Frontera Norte/El Colegio de Michoacán, Tijuana.

Hirai, Shinji, 2009, Economía política de la nostalgia. Un estudio sobre la transformación del paisaje en la migración transnacional entre México y Estados Unidos, Universidad Autónoma Metropolitana-Iztapalapa, México.

Hoelscher, Steven y Derek H. Alderman, 2004, "Memory and Place: Geographies of a Critical Relationship”, en Social \& Cultural Geography, vol. 5, núm.3, pp. 347-355.

Jaworsky, Bernadette Nadya et al., 2012, "New Perspectives on Immigrant Contexts of Reception. The Cultural Armature of Cities", en Nordic Journal of Migration Research, vol. 2, núm. 1, pp. 78-88.

Kong, Lily, 2001, “Mapping 'New' Geographies of Religion: Politics and Poetics in Modernity”, en Progress in Human Geography, vol. 25, núm. 2, pp. 211-233.

, 2012, "Ambitions of a Global City: Arts, Culture, and Creative Economy in 'Post-Crisis' Singapore”, en International Journal of Cultural Policy, vol. 18, núm. 3, pp. 279-294.

Legg, Stephen, 2007, "Reviewing Geographies of Memory/Forgetting”, en Environment and Planning A, vol. 39, núm. 2, pp. 456-466.

Levitt, Peggy y Nina Glick Schiller, 2004, “Conceptualizing Simultaneity: A Transnational Social Field Perspective on Society”, en International Migration Review, vol. 38, núm. 3, pp. 1002-1039.

López Cortés, Eliseo, 1999, Último cielo en la cruz: cambio sociocultural y estructuras de poder en los Altos de Jalisco, Universidad de Guadalajara/El Colegio de Jalisco, México.

Macdonald, Sharon, 2013, Memorylands: Heritage and Identity in Europe Today, Routledge, Londres. 
Mamadouh, Virginie, Olivier Kramsch y Martin van der Velde, 2004, "Articulating Local and Global Scales", en Tijdschrift voor Economische en Sociale Geografie, vol. 95, núm. 5, pp. 455-466.

Martínez Cárdenas, Rogelio, 2011, Turismo espiritual: una alternativa de desarrollo para las poblaciones, Consejo Estatal de Ciencia y Tecnología de Jalisco/Universidad de Guadalajara, Guadalajara.

Martínez Cárdenas, Rogelio y María del Carmen Mínguez García, 2014, “La Ruta Cristera: valoración de un producto turístico religioso”, en Procesos sociales y económicos, y territoriales en América Latina: actores, escalas. VIII Congreso Internacional de Geografía de América Latina: revisando paradigmas, creando alianzas, Asociación de Geógrafos Españoles de América Latina, Madrid, pp. 1569-1584. Disponible en línea: <https://www.ucm.es/data/cont/docs/539-2014-11-01-Martu00EDnez\%20Cu00E1rdenas\%20y\%20Mu00EDnguez\%20Garcu00EDa. pdf>. Consultado el 18 de agosto de 2015.

Meyer, Jean, 1973, La Cristiada, t. 1: La guerra de los cristeros, Siglo XXI Editores, México.

Morán, Rodolfo, 2000, "Representación religiosa de los mexicanos exiliados”, en Estudios Jaliscienses, núm. 39, pp. 5-17.

Muzaini, Hamzah, 2013, "Scale Politics, Vernacular Memory and the Preservation of the Green Ridge Battlefield in Kampar, Malaysia”, en Social \& Cultural Geography, vol. 14, núm. 4, pp. 389-409.

Odgers, Olga, 2008, “Construcción del espacio y la religión en la experiencia de movilidad. Los santos patronos como vínculos espaciales en la migración México-Estados Unidos”, en Migraciones Internacionales, vol. 4, núm. 3, pp. 5-26.

Peña, Guillermo de la y Renée de la Torre, 1990, “Religión y política en los barrios populares de Guadalajara”, en Estudios Sociológicos, vol. VIII, núm. 24, pp. 571-602.

—_ 1992, "Microhistoria de un barrio tapatío: Santa Teresita, 1930-1980”, en Carmen Castañeda (comp.), Vivir en Guadalajara. La ciudad y sus funciones, Ayuntamiento de Guadalajara, Guadalajara, pp. 119- 138.

Pratt, Mary Louise, 2006, “¿Por qué la Virgen de Zapopan fue a Los Ángeles? Algunas reflexiones sobre la movilidad y la globalidad”, en A Contracorriente, vol. 3, núm. 2, pp. 1-33.

Quiroz, Belem, Ruta Cristera en los Altos de Jalisco. Disponible en línea: <http://rutacristera.blogspot.mx/>. Consultado el 1 septiembre de 2015.

Rivera, Liliana, 2011, "Las lógicas del involucramiento transnacional. El engranaje de un circuito migratorio", en Marcela Ibarra y Liliana Rivera (eds.), Entre contextos locales y ciudades globales. La configuración de circuitos migratorios Puebla-Nueva York, Universidad Iberoamericana Puebla, Puebla, pp. 33-78.

Rostas, Susanna y André Droogers, 1995, "El uso popular de la religión popular en América Latina: una introducción”, en Alteridades, vol. 5, núm. 9, pp. 81-91.

Segato, Rita Laura, 2007, La nación y sus otros. Raza, etnicidad y diversidad religiosa en tiempos de políticas de la identidad, Prometeo, Buenos Aires.

Tapia Santamaría, Jesús, 1986, Campo religioso y evolución política en el Bajío zamorano, El Colegio de Michoacán, Zamora.

Torre, Renée de la, 2008, "La religiosidad peregrina de los jaliscienses: vírgenes viajeras, apariciones en los no lugares y santos polleros", en E-misférica, vol. 5, num. 1. Disponible en línea: <http://hemisphericinstitute.org/journal/5.1/esp/es51_pg_delatorre.html>. Consultado el 30 de enero 2015.

Torre, Renée de la y Cristina Gutiérrez Zúñiga, 2007, Atlas de la diversidad religiosa en México, Centro de Investigaciones y Estudios Superiores en Antropología Social, México.

Torre, Renée de la y Fernando Guzmán Mundo, 2010, "Santo Toribio, de mártir de los Altos a santo de los emigrantes", en María RodríguezShadow y Ricardo Ávila (comps.), Santuarios, peregrinaciones y religiosidad popular, Centro Universitario de Ciencias Sociales y Humanidades-Universidad de Guadalajara (colección Estudios del Hombre, serie Antropología, núm. 25), Guadalajara, pp. 107-128.

Truax Partida, E. Martha, 2011, El Señor del Calvario, Cristo de los migrantes, en California: la construcción de la identidad tras el ritual religioso, tesis de maestría en comunicación y política, Universidad Autónoma Metropolitana-Xochimilco, México.

Turner, Victor, 1980, La selva de los símbolos, Siglo XXI Editores, Madrid.

Valenzuela, José Manuel (coord.), 1992, Entre la magia y la historia. Tradiciones, mitos y leyendas de la frontera, Programa Cultural de las Fronteras-El Colegio de la Frontera Norte, Tijuana.

\section{Entrevistas}

Alfredo Jiménez, Jalostotitlán, Jalisco, febrero de 1992.

Estefanita y Asunción Jiménez González, Santa Ana de Guadalupe, Jalisco, febrero de 1992.

Gabriel González, Santa Ana de Guadalupe, Jalisco, 29 de diciembre de 2001. 